\title{
Missio hominum for social justice in South Africa: From missio Dei to missio hominum
}

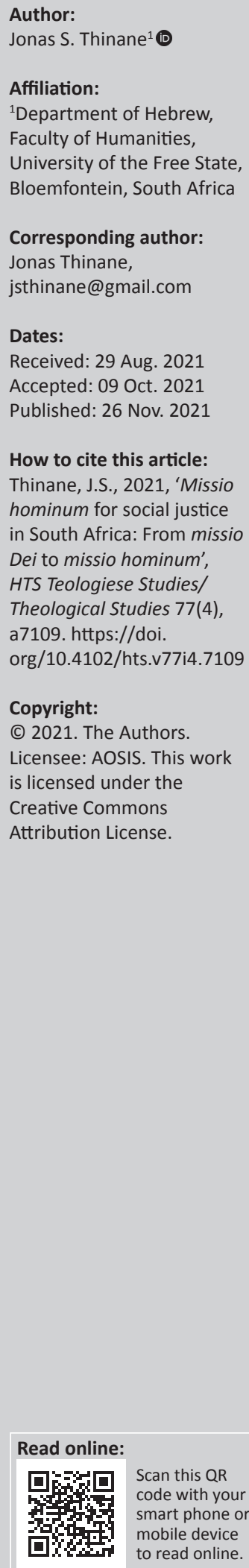

Decades after the fall of apartheid, South Africa continues to face problems such as racism, heterosexism, sexism, ableism, xenophobia, and gender-based violence leading to feminicide, which undermines all efforts being made to achieve social justice. Every Christian mission begins or flows out from missio Dei and has a common endeavour to achieve its goal. This article examines missio hominum as the new fundamental paradigm from the perspective of Nico Smith. It believes that when Smith saw the need for missio hominum, social justice was thought of as a prerequisite for the accomplishment of missio Dei's goal. It examines how he developed the missio hominum paradigm with the aim of advocating for social justice in South Africa. It perceives a potential and a fundamental element for social justice in this new paradigm. Significantly, missio hominum represents a fundamental theological paradigm by which human action is integrated or linked with divine action in order to achieve the goal of the missio Dei. It provides an overview of the literature relating to the featured works on Christian mission and social justice. To the best of the author's knowledge, little or no work has been published on missio hominum as a missiological paradigm on the way to social justice.

Contribution: Missio hominum from the perspective of Nico Smith is described here as a new fundamental missiological paradigm aimed at bringing social justice to South Africa. This paradigm integrates the active participation of all people in the broader discourse of the missio Dei and its fulfilment. Adoption of this paradigm will enrich the field of theology in general and missiology in particular as it expands human participation in missio Dei.

Keywords: missio Dei; Nico Smith; missio hominum; missio ecclesiae; social justice.

\section{Introduction}

In recent years, the paradigm of the missio Dei has been seen from the point of view of the Willingen Conference of the International Mission Council (IMC) in 1952, in which this form of mission was understood as a result of the nature of God or as an inherent mission of God in which God the Father sent God the Son and together sent God the Holy Spirit into the world. The viewpoint has since risen to prominence in missiology as it continues to attract theological and scientific attention as the most important theological rediscovery of the 20th century. Equally, research focusing on human participation in missio Dei received substantial interest broadly within theology and missiology in particular.

Several missiologists such as Kritzinger (1987), Bosch (1991, 2011), Smith (2002), Engelsviken (2003), Mashau (2012), Saayman (2013), Knoetze and Mwangi (2018), Whitworth (2019), Cronshaw (2020), and many more have written extensively about Missio Dei paradigm as they sought to locate human participation in partnership with God towards achieving its goal. Of particular interest for this article is: 'From Missio Dei to Missio Hominum: En route in Christian mission and missiology' (Smith 2002), wherein he introduced missio hominum (mission of human beings) as the new missiological paradigm to place human participation in the broader context of missio Dei, and more broadly, proposing its use for social justice in South Africa.

Firstly, in order to put Smith's views and the introduction of the missio hominum paradigm within the course of social justice in perspective, this article will introduce and discuss the concept of justice in relation to God's justice within the broader discussion of social justice in South Africa. Secondly, it will incorporate social justice into missio Dei, as outlined by Nico Smith on his journey from missio Dei to missio hominum. 


\section{The concept of justice}

This article is fully aware that there is a qualitative difference between what could be understood as God's justice and human justice. It does not seek to compare or confuse the two, but rather to unite or consolidate them by advocating for social justice as an imperative in the light of or from the perspective of God's justice. Suffice it to say that these two forms of justice share compassionate concern for the poor and marginalised in a society. In this contribution, justice is important and relevant insofar as it seeks to enable all human beings to actively participate fairly in the object of the missio Dei.

There are arguably several biblical terms that suggest or point to the concept of justice. One of such terms in the Old Testament is the Hebrew noun משפט (mishpat), which is used in the Hebrew Bible to refer to justice that is aligned to the will of God. The second Hebrew term equivalent or parallel to mishpat is the noun צדק (sedeq or tzedek), which means justice or righteousness. These two terms mishpat and sedeq are equally used in the Hebrew Bible scriptures such as Amos 5:24, Psalm 72:2, Ecclesiastes 5:7, 8, Leviticus 19:15, Job 29:14 and Isaiah 1:27 to refer to a form of justice that is associated with fair treatment of the poor, the fatherless, widows in line with God's ruling or will (Bassey 2016:1353-1354; Domeris 2016:85-88).

In the New Testament or the Greek Bible, the Greek word

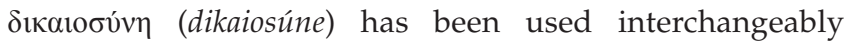
to refer to or correlate human and divine justice or righteousness. According to Ellington (2016), there is a broad relationship between the terms justice and righteousness. He substantiated this by first presenting their linguistic relationship as evidenced in scriptures such as Acts 17:31, where comparative translations such as the NRSV speaks of God who will judge in righteousness, whilst the same scripture in the NIV speaks of God who will judge in justice. He also indicated that several scriptures in Isaiah such as Isaiah 1:21 treats righteousness and justice as a parallel pair; this pair is also used by Apostle Paul in his letters to Corinthians (Ellington 2016:185-188). Scriptures that bear this expression, include but are not limited to Matthew 20:1-16, Luke 1:75, John 16:8-10, Acts 10:35, Romans 1:17 and 1 Corinthians 1:30, refer to justice or righteousness as a condition that is acceptable to God (Ellington 2016:175-177; Welzen 2013:89-94). The concept of justice is underscored by the principles or qualities such as reasonableness, sensibleness, reciprocation, inclusion, equality, respect for other people, judiciousness and fairness or impartiality at all levels of a society.

Jesus Christ approached the question of justice from the perspective of social concern for the hungry (Mt 25:34-40; Lk 3:11), looking after the widows (Lk 18:1-8; 21:1-4), to heal the sick (Mt 14:14; 15:30), restore vision to the blind (Mk 10:4652; Mt 20:29-34), restore movement to the lame (Mt 21:1; Jn $5: 1-9)$, reunite or reintegrate the outcasts into communities (Mk 1:40-45; Jn 8:3-11) and even cast out demons (Mt 8:16; Mk 9:20-21). For him, all of these questions represented injustices that put those who were in the minority at a disadvantage. By nourishing, healing, restoring and deeply caring for them, he tore down walls that separated them from equal enjoyment of social advantage. An unpretentious saying like: 'may the Sinless one among you, throw a stone at her' correctly restored social equality in relation to sin, and even called for fair treatment of the woman who was brought to him. The lame man, who sat by the pool of Bethesda in the Sheep Gate in Jerusalem for 38 years, felt the injustice of his own society and therefore complained to Jesus, saying:

'Sir, I have no one to put me into the pool when the water is stirred up, and while I am making my way, someone else steps down ahead of me'.

This man felt overpowered, discriminated against, and disadvantaged or treated unfairly by members of his own society who invalidated his presence or were not sensible enough to consider his illness as it prevented rapid movements. In inviting his disciples, including his general followers, to his ministry, Jesus wanted all people to partake in a form of justice or righteousness acceptable to God that would ultimately tear apart the walls of division and thereby achieve the goals of the missio Dei.

\section{God of justice}

Biblical writings such as in Isaiah 5:16 declares that God is exalted by righteousness whilst His holiness is proven by His just deeds; in Deuteronomy 32:4, wherein God is called the righteous and just God because his ways are always righteous. Psalm 10:14-18 speaks of God marked by zeal for justice because of his love for the socially powerless. Psalm 11:7 declares that God is righteous and loves justice. All of these scriptures affirm that righteousness or justice is inherently rooted in God's character and by extension in missio Dei along with all other Christian missions. Knoetze and Mwangi (2018) are spot-on in suggesting that all biblical socio-ethical teachings are underscored by the concept of missio Dei (Knoetze \& Mwangi 2018:2).

The law of God, as clearly stated in the Ten Commandments of the Old Testament (Exodus 20), reflects the principles on which God's form of justice is based, particularly the second aspect, which focuses on human social morality. These moral imperatives remain a clear reflection of God's character and his justice. More clarity is further gained from Jesus in Matthew 22:37-39, 'Love the Lord your God with all your heart and with all your soul and with all your mind.' This is the first and greatest commandment. The second is: 'Love your neighbour as yourself'.

In addition, all the teachings of Jesus during his earthly ministry, especially from the perspective of Matthew, point to the commandment of righteousness in the world. In Luke 11:42, he specifically shamed Pharisees for neglecting justice and the love of God whilst focusing on religious observance. According to Jesus Christ, any failure to show justice to the poor and marginalised is contrary to the true nature of God. He illustrates this through the parable of the sheep and goats, in which the sheep (righteous) are separated from the goats, referring to the sheep as those who have demonstrated justice 
or righteousness to the poor, the sick and those in bondage (Mt 25:32-36). Similarly, in Matthew 6:33, Jesus teaches the crowd that they must seek God's kingdom and righteousness first and everything else will follow. Bosch (2011) interpreted this to mean that Jesus is asking human beings to concern themselves with practice of justice towards those who are marginalised as this is what the kingdom of God is all about (Bosch 2011:72-73). It goes without saying that in order for human beings to be true reflections of God (the image of God), they must first strive for uprightness and justice virtues. Only when God's justice is fully demonstrated in the world can believers be satisfied that the kingdom of God has arrived. Characteristically, the true manifestation or existence of the kingdom of God as a reality in the world will be marked by human actions of God-inspired form of social justice.

\section{Social justice in South Africa}

At the time when societal efforts were aimed at the eradication of apartheid in South Africa, most people, in particular Christians justifiably believed that once it was eradicated, social justice would automatically become the order of the day. Bosch (2011) observed a similar scenario with the system of slavery that led to the second civil war. He observed that most Christians, especially evangelicals, believed that slavery was a curse that needed to be removed. Many of these Christians were convinced that after the abolition of slavery, justice would automatically prevail (Bosch 2011:327). In both cases, however, contrary to these utopian expectations, the realities were thoroughly different. Social problems on the contrary gained momentum rather than diminishing. In South Africa, what should have been the end of apartheid has turned into other forms of social injustices.

Although the end of apartheid in 1994 brought some positive reforms, racial tensions continue to increase among South Africans (Puttick 2012:1-3; Walker 2005:41-54). Whilst South Africa is seen as the first country to give gays, bisexuals and lesbians clear protection of their rights and sexual orientation, cases of heterosexism continue to increase as these groups of people experience prejudice and discrimination in various social platforms (De Ru 2013:221-250; Francis \& Msibi 2011:160-161; Francis \& Reygan 2016:180-193; Govender 2016:237-256). During South Africa's transition to democracy, commitments and promises were made that South Africa's new democratic Constitution will reflect and epitomise women's struggle for equality with men. Unfortunately, equality for women remains a challenge as they continue to be discriminated against men or less favoured by different social systems (Andrews 2007:1-4; Segalo 2015:70-79; Shepherd 2017:1-8). Although the new democratic government wanted to introduce reforms to eradicate inequality between abled and disabled people, many disabled people do not have access to equal employment opportunities to this end and continue to be marginalised by sections of society (Chiwandire \& Vincent 2017:1-9; Dube 2007:14-16; Lang et al. 2018:166-171). Although xenophobia existed in South Africa before 1994, the further progression of democracy in 2008 and 2015, respectively, encountered an increasing series of xenophobic violence. During these years, xenophobic attacks occurred in several parts of South Africa, in which both foreigners and South Africans died (Beetar 2018:122-135; Durokifa \& Ijeoma 2017:3293-3301; Mlambo 2019:53-64). Incidents of gender-based violence (GBV), particularly against black South African women during apartheid, were widespread. However, under the democratic dispensation, this has evolved into a pandemic in which women suffer physical, emotional, psychological and sexual harm almost daily, with women usually being murdered by men (Armstrong 1994:35-39; Dlamini 2020:583-590; Mathews, Jewkes \& Abrahams 2014:1-16).

The picture drawn here is more gloomy than hopeful for attaining social justice in South Africa. Twenty-seven years into the new democratic dispensation, the road ahead seems more bleak than promising. Rather, this indicates towards a societal failure to adequately eliminate inequalities and remove obstacles on the way to social justice. This simply means that with all these forms of injustices, social justice does not seem to be the order of the day. Nico Smith, after realising the nature of social injustices of apartheid, felt the need to move from missio Dei to missio hominum as the new paradigm through which all people can rise to the task of fulfilling the mission of missio Dei. By properly understanding missio Dei, he developed the missionary framework that advocated a paradigm that sees social justice from the perspective of missio Dei.

\section{Missio Dei and social justice}

According to Thinane (2021), missio Dei is a Latin theological expression that pronounces God's mission as it includes His plan for human salvation in the world (Thinane 2021:2). This definition agrees with Whitworth (2019), who also stated that missio Dei is a Latin expression for the mission of God (Whitworth 2019:17). missio Dei is primarily about God's active character in the reconciliation of the world with himself, that is, it is exclusively about God himself in his own plan of salvation for his creation. Saayman (2013) formulated this differently, speaking of missio Dei as the eternal project of the creator, sustainer and liberator for the created world, in which humans can only participate (Saayman 2013:135), whilst Arthur (2009) puts it similarly as:

The Triune God is the instigator of mission and through the sacrifice of the Son and the empowering presence of the Spirit he is also the one who guarantees the success of mission. (p. 3)

This is consistent with Engelsviken (2003:482) who argued vehemently that: 'It is this Trinitarian basis of mission that should form the foundation of any understanding of missio Dei', it also received support from both Flett (2014) and Cronshaw (2020), as they equally argued that missio Dei is inherently missio Trinitas, in which the Trinitarian God invites his people to join in (Cronshaw 2020:119-141; Flett 2014:69). Kritzinger (1987) as observed and interpreted by Mashau (2012), perceived missio Dei as hermeneutical key that considered God as a missionary God who advances his kingdom by reaching out to humanity (Kritzinger 1987:7; Mashau 2012:5). 
Over a long period of time, the concept of missio Dei has become an important paradigm within missiology to shed light on the role of other Christian missions such as missio Christos, missio spiritus and missio ecclesiae. According to this paradigm, God the Father, the Son and the Holy Spirit are at the centre of God's salvation mission. This is closely observed by Bosch (2011) who affiliated to the views of Aagaard (1973, 1974) and Moltmann (1977) in writing that:

In the new image, mission is not primarily an activity of the church, but an attribute of God. God is a missionary God. It is not the church that has a mission of salvation to fulfil in the world; it is the mission of the Son and the Spirit through the Father that includes the church. Mission is thereby seen as a movement from God to the world; the church is viewed as an instrument for that mission. There is church because there is mission, not vice versa. To participate in mission is to participate in the movement of God's love towards people, since God is a fountain of sending love. (Aagaard 1973:13, 1974:423; Bosch 2011:400; Moltmann 1977:64)

Bosch (2011) reported sequentially how the concept of the missio Dei came about. He pointed out that Barth ([1932] 1957) was the first person to introduce mission as an activity of God himself. After Barth's introduction, Karl Hartenstein's similar conviction followed in his Die Mission als theologisches problem. This was followed by the confession of the German delegation at the Tambaram meeting of the IMC in 1938 as it expressed the conviction that new heaven and new earth will only be realised through a creative act of God. Ultimately, missio Dei culminated as a paradigm at the Willingen Conference of the IMC in 1952 wherein mission was correctly understood as resulting from the very nature of God or as inherently Mission of God whereby God the Father sent God the Son and sent God the Holy Spirit in the world together (Bosch 2011:399). To explain the sending sequence, Engelsviken (2003) stated that the Trinitarian God as the acting subject in the project of missio Dei, becomes both the sender and the one being sent at the same time (Engelsviken 2003:483).

According to Bosch (2011), God's justice is inherently linked to his eternal saving activities, whilst human righteousness involves human efforts to respond to God's goodness. He linked them together and wrote: 'God's justice, then, is his saving activity on behalf of his people. Human justice is the effort we make to respond to God's goodness by carrying out his will'. He also pointed out that the obligation to justice, which binds God and people, manifests itself as active belief in God's saving acts (Bosch 2011:73). Similarly, Harold (2019) pointed out that missio Dei enforces the understanding of the Church of Christ as part of a mission that includes the practice of social justice (Harold 2019:1). In this way, the church, as part of the social institutions of every society, becomes involved in missio Dei's activities through its interaction with individuals, society as a whole and social institutions, which include economic institutions, political institutions, religious institutions and educational institutions, amongst others. The church becomes the serving body as it seeks to invite the entire society into fulfilling the ultimate goal of Missio Dei. This fact is accurately captured by Taylor (1899) by arguing that whenever other secular social institutions fail to meet and cater for people's needs, the church has the obligation to represent the serving body of God by incarnating the Christ's spirit in dealing with other social institutions (Taylor 1899:311). Furthermore, Harold (2019) came to the conclusion that missio Dei, as a practice-oriented paradigm, takes into account people's social realities (Harold 2019:7). This means that any failure by people to ensure or achieve social justice in the world will result in the failure to achieving the goal or objective of missio Dei. In fact, Platter (2013) clearly states that people are only participants in the missio Dei if they act within the framework of social justice. He then concluded: 'To know God is to act justly, and to act justly, properly conceived, is to know God and the presence of the Spirit' (Platter 2013:4, 12).

\section{Nico Smith and social justice}

Firstly, it is important to briefly outline the South African apartheid context in which Nico Smith grew up and developed the concept or necessity of the missio hominum paradigm. In short, apartheid as an extension of European colonialism was a repressive system characterised by a policy that regulated relations between the white minority and the black majority. This system was in place in South Africa from almost the 1940s to the 1960s, when the Nationalist Party tightened it until the late 1990s. Under this regime, slaverylike oppression was a daily experience of black people, as white people were led to believe that they were superior to black people and denied their humanity to such an extent that it enjoyed the support of some Christian churches, who carried or conducted mission in ways that gave it an acceptable face and allowed conducts, which sought to undermine the humanity and the image of God in black people (Harvey 2001:64-74; Mhlauli, Salani \& Mokotedi 2015:203-219; Nagan 1998:404-406; Smith 2002:6). In Christian Fobbe's view (a missionary from the Berlin Missionary Society in Germany): apartheid was 'a political system that showed no respect for the blacks and violated their human dignity' (Smith 2002:9).

Smith saw these injustices not only as obstacles to the realisation of social justice, but rather as obstacles to the free participation of people in order to achieve the goal of the missio Dei. For him, the missio hominum was the only missing missiological paradigm that is urgently needed to outline the expectations of active human participation in the missio Dei. The fulfilment of the goal of missio Dei could not come about if Christians were not willing to work with other people to ensure social justice as a predicate for active participation in missio Dei. Then it dawned on him that God would only complete his salvific work which aims at reconciling all people with himself, only when social justice has been fully realised.

Immediately, he saw apartheid for what it was an exclusive evil system. Under this system, two different nations lived in one country, one nation (white people) being wealthy at the 
expense of the other nation (black people). It flourished by granting unequal opportunities, economic and political power, only to the white minority. He immediately realised that this form of social injustice inflicted on the black majority was taking people, especially white people, further from fulfulling the purpose of missio Dei.

Smith explained how he distanced himself from the injustices black people suffered in South Africa during this period. He believed that the apartheid government knew what was best for black people and that was why he could not interfere in their situation, no matter how uncomfortable and painful it appeared. Admitting his disregard of black peoples' plight and human dignity, he wrote: 'I had to admit to myself that my focus was completely on God and the church, and not on the people'...further he added, 'I had not accepted the people who needed to be recognised as human beings, whom I needed to respect and acknowledge as equal fellow human beings'. In his view, cultural and political affairs were far from the task of missio Dei (Smith 2002:9-10). Excellently, Bosch (2011) put the question of politics into perspective, arguing that whilst Jesus Christ had no intention of advocating a political kingdom, his ministry was never apolitical either. Instead, as he puts it: 'His politics was, however, one of peacemaking, of reconciliation, of justice, of refusing vengeance and, above all, of love of enemy' (Bosch 2011:71). Precisely for these reasons, Engelsviken (2003) argued that the Trinitarian God, in the context of the Missio Dei, uses the church as an instrument to serve the world in all its needs, including social and political affairs (Engelsviken 2003:483).

Such was Smith's understanding of the role of the church in social affairs, notwithstanding the fact that Christians in particular are in the privileged position of knowing the forms of social justice advocated by the teachings of Christ. Scholars such as Taylor (1899) argued unequivocally that there will be times when it will be necessary to convert pulpits into lecture halls to discuss economics and politics or even offer days of worship in free forums to discuss social theories (Taylor 1899:311). Van Reken (1999) concluded that the church, as another institution of the society, should speak out whenever regimes pursue evil social goals (Van Reken 1999:201). This agrees with Genovese (2015), who argued that it is up to religious systems such as Christianity to speak politically when secular institutions fail to ensure social justice (Genovese 2015:1-9). Pillay (2017) showed that the Christian religion has always been involved in driving the transformation in societies, as it has sided with the poor and marginalised people in the face of secular systems of oppression (Pillay 2017:1-12). This view is also supported by Bosch (2011), as he mentioned that the New Testament Witnesses are about a community of people who have stood up for peace and justice in the face of tribulation, hatred and oppression (Bosch 2011:52).

\section{Missio hominum for social justice}

Missio hominum can be broadly defined as a Latin theological expression consisting of two Latin terms missio for 'mission' and hominum for 'human' implying human mission or mission of humans. Leaving the avenue of the missio Dei, Smith consolidated the concerns of social justice in the human context to develop a paradigm (missio hominum) by which human action is linked with divine action to achieve the goal of missio Dei. Through this paradigm, human activity at the ground level is firstly linked to missio Dei and later other missions such as missio Christos, missio spiritus and missio ecclesiae.

Using missio hominum as the basic and fundamental paradigm for social justice in South Africa, Smith indicated that missio hominum is about believers, especially Christians, who actively intervene in the unjust affairs of other peoples, to show or demonstrate Christ's love and deep concern for their plight (Smith 2002:18). Missio hominum as a paradigm dawned on him when he realised that white Christians, beneficiaries of apartheid, were practicing extreme social injustice against black people by ignoring or disregarding their plight. $\mathrm{He}$ realised that by distancing themselves from the suffering of black people in South Africa was and still is against the agenda of a socially righteous life as prescribed by God in Jesus of Nazareth, as he too during his earthly ministry sought to destroy forces that imposed unjust human rule. In fact, Bosch (2011) addressed this point in arguing that inherently or as a matter of course, any mission that flows from missio Dei involves or consist of believers who are sensitive to the needs of others, believers who recognises injustices, oppression, suffering and the plight of all people (Bosch 2011:82-83). From this perspective, missio hominum calls on Christians to play an important role with other people in ensuring social justice that reflects Christ's agenda and enables active human participation in missio Dei. Bosch (2011) gave an example of this as he argued about the failure of Christians to live in accordance with the standards as outlined by Jesus Christ, particularly on the Sermon on the Mount (Mt 5:20), he wrote: 'it is imperative for the church-inmission to include the superior justice of the Sermon on the Mount in its missionary agenda' (Bosch 2011:71).

Smith acknowledged that amidst the relationship between the Church and missio Dei, it is the responsibility of each Christian to explore ways to become an active core-worker of God in his own mission to the world. Following this logic, missio hominum becomes a paradigm through which all individuals are personally invited into a central working relationship with God and his Church (Smith 2002:11). According to this paradigm, the role of the Church in fulfilling the purpose of the missio Dei is as important as the role that all human beings should play within the broader expectations of the missio Dei. God's mission in this way requires that the Church, working with all other persons, have an equal responsibility for ensuring social justice as a prerequisite for achieving the purpose of missio Dei. This means that the missio hominum paradigm simultaneously recognises the central importance of the presence of God in missio Dei, and at the same time invites all people to form a core working relationship in order to accomplish the goal of missio Dei.

After all, all human beings are called in God's image to ensure social justice in every society by acquitting the 
innocent, condemning the guilty and exposing unjust acts (2 Chr 19:5-7). They should not falsify justice and favour the rich over the need of the poor, but endeavour to treat all people equally before God (Lv 19:15; Ex 23:3). Christ urged all people to act righteously and to care for the weak, widows, orphans and the marginalised (Lk 19:1-10). Missio hominum invites all people to expressly or clandestinely choose to imitate the teachings of Jesus of Nazareth or to live their lives accordingly by ensuring social justice. This paradigm invites all people to act righteously in the light of Jesus' example as he remains the only perfect example and master of social justice through his actions on earth.

\section{Conclusion}

Firstly, this article focused on the Missio Hominum paradigm from Nico Smith's perspective on social justice in South Africa. This was performed by discussing the concept of justice in relation to the justice of God within the broader discussion of social justice. Secondly, it incorporated the need for social justice into missio Dei, as narrowed down by Nico Smith on his way towards understanding the missio Dei to the missio hominum. The main conclusion from this work is that missio hominum, as the new missiological paradigm that calls for active human participation in missio Dei, can be used to advocate for social justice in the world, in Africa and in South Africa in particular. As a new paradigm within missiology, missio hominum provides potential avenues for future research. The world as a whole, Africa in general and South Africa in particular, can address all forms of social imbalances by using missio hominum as a paradigm that seeks to make the kingdom of God a reality. Further scientific evaluation and exploration of this paradigm will provide some important clues on how to address the issue of social justice or its lack around the world, particularly in Africa and South Africa.

\section{Acknowledgements Competing interests}

The author declares that he has no financial or personal relationships that may have inappropriately influenced him in writing this article.

\section{Author's contributions}

J.S.T. is the sole author of this research article.

\section{Ethical considerations}

This article followed all ethical standards for research without direct contact with human or animal subjects.

\section{Funding information}

This research received no specific grant from any funding agency in the public, commercial, or not-for-profit sectors.

\section{Data availability}

Data sharing is not applicable to this research as no new data were created or analysed in this article.

\section{Disclaimer}

The views and opinions expressed in this article are those of the author and do not necessarily reflect the official policy or position of any affiliated agency of the author.

\section{References}

Aagaard, A.M., 1973, 'Trends in Missiological thinking during the sixties', International Review of Mission 62(245), 8-25. https://doi.org/10.1111/j.1758-6631.1973. tb01047.x

Aagaard, A.M., 1974, 'Missio Dei in katholischer Sicht', Evangelische Theologie 34 420-433. https://doi.org/10.14315/evth-1974-jg35

Andrews, P., 2007, From gender apartheid to non-sexism: The pursuit of women's rights in South Africa, viewed 20 August 2021, from http://ssrn.com/ abstract $=1006521$.

Armstrong, S., 1994, 'Rape in South Africa: An invisible part of apartheid's legacy', Gender\&Development 2(2),35-39. https://doi.org/10.1080/09682869308520009

Arthur, E., 2009, Missio Dei: The mission of God, viewed 20 August 2021, from https:// www.kouya.net/upload/missionofgod.pdf.

Barth, K. [1932] 1957, 'Die Theologie und die Mission in der Gegenwart', in Theologische fragen und Antworten, vol 3, pp. 100-126, Evangelischer Verlag, Zollikon-Zürich.

Bassey, S.A., 2016, Christian perspective of social justice, viewed 23 August 2021, from https://www.academia.edu/29791848/CHRISTIAN_PERSPECTIVE_OF_SOCIAL_ JUSTICE.

Beetar, M., 2018, 'A contextualisation of the 2008 and 2015 xenophobic attacks: Tracing South African necropolitics', Current Sociology 67(1), 122-140. https:// doi.org/10.1177/0011392118807528

Bosch, D.J., 1991, Transforming mission: Paradigm shifts in theology of mission, 7th edn., Orbis Books, Maryknoll, NY.

Bosch, D.J., 2011, Transforming mission: Paradigm shifts in theology of mission, Orbis Books, Maryknoll, NY.

Chiwandire, D. \& Vincent, L., 2017, 'Wheelchair users, access and exclusion in South African higher education', African Journal of Disability 6, a353. https://doi. org/10.4102/ajod.v6i0.353

Cronshaw, D., 2020, 'Missio Dei is Missio Trinitas: Sharing the whole life of God, Father Son and spirit', Mission Studies 37(1), 119-141. https://doi.org/10.1163/15733831 12341699

De Ru, H., 2013, 'A historical perspective on the recognition of same-sex unions in South Africa', Fundamina 19(2), 1021-1545, viewed 20 August 2021, from http:// www.scielo.org.za/pdf/funda/v19n2/03.pdf.

Dlamini, J., 2020, 'Gender-based violence, twin pandemic to CoVID-19', Critical Sociology 47, 4-5. https://doi.org/10.1177/0896920520975465

Domeris, W., 2016, 'Meek or oppressed? Reading Matthew 5:5 in context', Acto Theologica 23(1), 131. https://doi.org/10.4314/actat.v23i1S.7

Dube, A.K., 2007, The role and effectiveness of disability legis/ation in South Africa, viewed 20 August 2021, from https://assets.publishing.service.gov.uk/media/ 57a08c5ce5274a27b2001155/PolicyProject_legislation_sa.pdf.

Durokifa, A.A. \& Ijeoma, E.O.C., 2017, 'The post-apartheid xenophobic attacks in South Africa: A reflection on government interferences', African Population Studies 33(1), 3293-3306. https://doi.org/10.11564/31-1-981

Ellington, D.W., 2016, 'So that we might become the righteousness and justice of God: Re-examining the Gospel in 2 Cor 5:21 for the Church's contribution to a better world', Missionalia 44(2). https://doi.org/10.7832/44-2-137

Engelsviken, T., 2003, 'Missio Dei: The understanding and misunderstanding of a theological concept in European churches and missiology', International Review of Mission 92(367), 481-497. https://doi.org/10.1111/j.1758-6631.2003.tb00424.x

Flett, J., 2014, A theology of Missio Dei, viewed 21 August 2021, from https://core. ac.uk/download/pdf/80685405.pdf.

Francis, D.A. \& Reygan, F., 2016, "'Let's see if it won't go away by itself": LGBT microaggressions among teachers in South Africa', Education as Change 20(3), 180-201. https://doi.org/10.17159/1947-9417/2016/1124

Francis, D. \& Msibi, T., 2011, 'Teaching about heterosexism: Challenging homophobia in South Africa', Journal of LGBT Youth 8(2), 157-173. https://doi.org/10.1080/19 361653.2011.553713

Genovese, F., 2015, 'Politics ex cathedra: Religious authority and the Pope in modern international relations', Research \& Politics 2(4), 205316801561280. https://doi. org/10.1177/2053168015612808

Govender, J., 2016, 'Social justice in South Africa', Civitas - Revista de Ciências Sociais 16(2), 237. https://doi.org/10.15448/1984-7289.2016.2.23076

Harold, G., 2019, 'An evangelical understanding of the Missio Dei as inclusion of socia justice: A critical theological reflection', Pharos Journal of Theology 100, viewed 21 August 2021, from https://www.pharosjot.com/uploads/7/1/6/3/7163688/ article_16_vol_100_2019_stellenbosch.pdf.

Harvey, R., 2001, The fall of apartheid the inside story from Smuts to Mbeki, viewed 22 August 2021, from https://www.sahistory.org.za/sites/default/files/archive-files/ robert_harvey_the_fall_of_apartheid_the_inside_book4me.org_.pdf.

Knoetze, J.J. \& Mwangi, R.K., 2018, “'Walking in the light" and the Missio Dei: Perspectives from the Anglican Church of Kenya', HTS Teologiese Studies/ Theological Studies 74(1), 4868. https://doi.org/10.4102/hts.v74i1.4868 
Kritzinger, J.J., 1987, 'Introducing missiology', in H.L. Pretorius, A.A. Odendal, P.J. Robinson \& G. Van der Merwe (eds.), Reflecting on mission in the African context pp. 1-10, Pro Christo Publications, Bloemfontein.

Lang, R., Schneider, M., Kett, M., Cole, E. \& Groce, N., 2018, 'Policy development: An analysis of disability inclusion in a selection of African Union policies', Development Policy Review 37(2), 155-175. https://doi.org/10.1111/dpr.12323

Mashau, T.D., 2012, 'A reformed perspective on taking mission and missiology to the heart of theological training', In die Skriflig/In Luce Verbi 46(2), a64. https://doi. org/10.4102/ids.v46i2.64

Mathews, S., Jewkes, R. \& Abrahams, N., 2014, “'So now I'm the man": Intimate partner femicide and its interconnections with expressions of masculinities in South Africa', British Journal of Criminology 55(1), 107-124. https://doi.org/ 10.1093/bjc/azu076

Mhlauli, M.B., Salani, E. \& Mokotedi, R., 2015, 'Understanding apartheid in South Africa through the racial contract', International Journal of Asian Socia Science 5(4), 203-219. https://doi.org/10.18488/journal.1/2015.5.4/1.4.203.219

Mlambo, D.N., 2019, 'A South African perspective on immigrants and xenophobia in post-1994 South Africa', African Renaissance 16(4), 53-67. https://doi. org/10.31920/2516-5305/2019/16n4a3

Moltmann, J., 1977, The Church in the power of the spirit: A contribution to messianic ecclesiology, SCM Press, London (first published in 1975).

Nagan, W., 1998, 'Law and post-apartheid South Africa', Fordham International Law Journal 12(3), viewed 22 August 2021, from https://core.ac.uk/download/ pdf/144226858.pdf.

Pillay, J., 2017, 'The church as a transformation and change agent', HTS Teologiese Studies/Theological Studies 73(3), a4352. https://doi.org/10.4102/hts.v73i3.4352

Platter, J., 2013, 'The trinity, social justice, and the Missio Dei: A Trinitarian construal of agency, treating social justice as paradigmatic of Christian action', Nazarene Theological Seminary, viewed 19 August 2021, from https://didache.nazarene.org/ index.php/volume-13-1/897-didache-v13n1-06-trinity-social-justice-platter1/file.
Puttick, K., 2012, 'First year students' narratives of "race" and racism in postapartheid South Africa', Unpublished master's thesis, University of the Witwatersrand.

Saayman, W., 2013, 'Mission as theological education: Is Christian mission history coming full circle? A German-South African case study', Missionalia 41(2), 133.

Segalo, P., 2015, 'Gender, social cohesion and everyday struggles in South Africa', Psychology in Society 49, 70-82. https://doi.org/10.17159/2309-8708/ 2015/n49a6

Shepherd, D., 2017, Post-apartheid trends in gender discrimination in South Africa: Analysis through decomposition techniques, viewed 20 August 2021, from from https://resep.sun.ac.za/wp-content/uploads/2017/10/wp-06-2008.pdf.

Smith, N., 2002, 'From missio Dei to missio hominum: En route in Christian mission and missiology', Missionalia 30(1), 4, viewed 03 October 2021, from https:// ixtheo.de/Record/1645606155.

Taylor, G., 1899, 'The social function of the Church', American Journal of Sociology 5(3), 305-321. https://doi.org/10.1086/210893

Thinane, J.S., 2021, 'Missio hominum as the compassionate response to socioeconomic and vaccine challenges during COVID-19 in South Africa', HTS Teologiese Studies/Theological Studies 77(3), a6544. https://doi.org/10.4102/ hts.v77i3.6544

Van Reken, C., 1999, 'The church's role in social justice', Calvin Theological Journal 34 198-202, viewed 16 August 2021, from https://www.calvin.edu/library/database/ crcpi/fulltext/ctj/68491.pdf.

Walker, M., 2005, 'Race is nowhere and race is everywhere: Narratives from black and white South African university students in post-apartheid South Africa', British Journal of Sociology of Education 26(1), 41-54.

Welzen, H., 2013, 'A hermeneutic of justice. Justice as discernment in Matthew', Acto Theologica 17, 89-109.

Whitworth, D.M., 2019, Missio Dei and the means of grace: A theology of participation, Pickwick Publications, Eugene, OR. 